\title{
Article \\ Copper Tricomponent Catalysts Application for Hydrogen Production from Ethanol
}

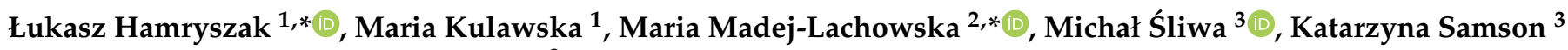 \\ and Małgorzata Ruggiero-Mikołajczyk ${ }^{3}$
}

1 Institute of Chemical Engineering, Polish Academy of Sciences, 5 Bałtycka Street, 44-100 Gliwice, Poland; maria.kulawska@gmail.com

2 Department of Biosystem Engineering and Chemical Processes, Opole University of Technology, 31 Sosnkowskiego Street, 45-272 Opole, Poland

3 Jerzy Haber Institute of Catalysis and Surface Chemistry, Polish Academy of Sciences, 8 Niezapominajek Street, 30-239 Krakow, Poland; ncsliwa@cyf-kr.edu.pl (M.Ś.); ncsamson@cyf-kr.edu.pl (K.S.); nbruggie@cyf-kr.edu.pl (M.R.-M.)

* Correspondence: lukasz.hamryszak@iich.gliwice.pl (Ł.H.); m.madej-lachowska@po.edu.pl (M.M.-L.); Tel.: +48-32-231-0811 (Ł.H.); +48-77-449-8774 (M.M.-L.)

check for updates

Citation: Hamryszak, Ł.; Kulawska, M.; Madej-Lachowska, M.; Śliwa, M.; Samson, K.; Ruggiero-Mikołajczyk, M. Copper Tricomponent Catalysts Application for Hydrogen Production from Ethanol. Catalysts 2021, 11, 575. https://doi.org/10.3390/catal11050575

Academic Editors: Anna Gancarczyk, Przemysław Jodłowski and Maciej Sitarz

Received: 26 February 2021

Accepted: 28 April 2021

Published: 30 April 2021

Publisher's Note: MDPI stays neutral with regard to jurisdictional claims in published maps and institutional affiliations.

Copyright: (c) 2021 by the authors. Licensee MDPI, Basel, Switzerland. This article is an open access article distributed under the terms and conditions of the Creative Commons Attribution (CC BY) license (https:/ / creativecommons.org/licenses/by/ $4.0 /)$.

\begin{abstract}
The application of copper-based catalysts in the production of pure hydrogen in the steam reforming of ethanol was performed. The tricomponent $\mathrm{Cu} / \mathrm{Zr}$ catalysts with about 4 mass $\%$ addition of nickel, cobalt, or cerium have been prepared in our laboratory. The properties of obtained catalysts were compared with bimetallic $\mathrm{Cu} / \mathrm{Zr}$ catalyst prepared and tested according to the same procedure. Catalytic tests were carried out in the continuous flow fixed-bed reactor in the wide temperature range of $433-593 \mathrm{~K}$ for initial molar ratio of ethanol to water equal to 1:3. Catalysts were characterized by XRD, TPR, $\mathrm{CO}_{2}-\mathrm{TPD}$, and TPO methods. $\mathrm{Cu} / \mathrm{Zr} / \mathrm{Ce}$ catalyst proved to be the best; hydrogen yield reached the value of $400 \mathrm{~L} /\left(\mathrm{kg}_{\text {cat. }} \cdot \mathrm{h}\right)$, selectivity towards carbon monoxide was below $0.5 \%$ and the one towards methane wasnot detected. Additions of Ni or Co did not bring significant improvement in activity.
\end{abstract}

Keywords: copper-zirconium catalysts; ethanol steam reforming; hydrogen fuel cells; hydrogen production; non-noble metal catalysts

\section{Introduction}

The rising energy production in all developed and developing countries causes the corresponding increase in the environment pollution. New restrictions and regulations require new clean technologies of high efficiency of energy generation [1]. Hydrogen is considered as a carrier of clean energy. Many methods of hydrogen production have been developed. The industrial production of hydrogen is currently carried out in the process of gasification of coal and other fossil materials, in the process of steam reforming of hydrocarbons (mainly methane), oxygenates (mainly methanol) [2,3], and from water electrolysis [4]. Many attempts have been made in recent decades to produce hydrogen from ethanol or bioethanol derived from any source of starch [5]. In the process of ethanol steam reforming (ESR) hydrogen is a product of highly endothermic catalytic reaction [6]:

$$
\mathrm{C}_{2} \mathrm{H}_{5} \mathrm{OH}+3 \mathrm{H}_{2} \mathrm{O} \leftrightarrow 2 \mathrm{CO}_{2}+6 \mathrm{H}_{2} \quad \Delta \mathrm{H}_{298}=+174 \mathrm{~kJ} / \mathrm{mol} .
$$

Besides this main reaction, many side and consecutive reactions occur, giving undesired by-products, e.g., carbon monoxide, methane, acetic acid, acetaldehyde, ethene, and others:

$$
\begin{array}{lr}
\mathrm{CH}_{3} \mathrm{CH}_{2} \mathrm{OH} \leftrightarrow \mathrm{CH}_{3} \mathrm{CHO}+\mathrm{H}_{2} & \Delta \mathrm{H}_{298 \mathrm{~K}}=+68.7 \mathrm{~kJ} / \mathrm{mol} \\
\mathrm{CH}_{3} \mathrm{CHO} \leftrightarrow \mathrm{CH}_{4}+\mathrm{CO} & \Delta \mathrm{H}_{298 \mathrm{~K}}=-19.0 \mathrm{~kJ} / \mathrm{mol}
\end{array}
$$




$$
\begin{array}{cc}
\mathrm{CH}_{4}+\mathrm{H}_{2} \mathrm{O} \leftrightarrow \mathrm{CO}+3 \mathrm{H}_{2} & \Delta \mathrm{H}_{298 \mathrm{~K}}=+206.1 \mathrm{~kJ} / \mathrm{mol} \\
\mathrm{CH}_{3} \mathrm{CH}_{2} \mathrm{OH} \leftrightarrow \mathrm{C}_{2} \mathrm{H}_{4}+\mathrm{H}_{2} \mathrm{O} & \Delta \mathrm{H}_{298 \mathrm{~K}}=+45.0 \mathrm{~kJ} / \mathrm{mol} \\
\mathrm{C}_{2} \mathrm{H}_{4} \leftrightarrow 2 \mathrm{C}+2 \mathrm{H}_{2} & \Delta \mathrm{H}_{298 \mathrm{~K}}=-52.3 \mathrm{~kJ} / \mathrm{mol} \\
\mathrm{C}_{2} \mathrm{H}_{4}+2 \mathrm{H}_{2} \mathrm{O} \leftrightarrow 2 \mathrm{CO}+4 \mathrm{H}_{2} & \Delta \mathrm{H}_{298 \mathrm{~K}}=+210.0 \mathrm{~kJ} / \mathrm{mol} .
\end{array}
$$

Various stages of this process depend on process parameters and catalysts used $[7,8]$. To deal with such a complex process, the complicated catalytic systems with improved selectivity to hydrogen have been developed. The biggest problem is developing high resistance to carbon deposition on the catalyst surface and, at the same time, minimalization of carbon monoxide formation. Carbon monoxide is a strong poison that deactivates the proton exchange membrane fuel cell (PEMFC) catalyst. The system of low temperature PEMFC cannot accept more than $10 \mathrm{ppm}$ for efficient operation, while high-temperature PEMFC tolerates supply of gas containing up to 5 vol. \% of CO [8].

Early investigations on ESR catalysts were focused on application of noble metals as main component of catalysts: rhodium, platinum, ruthenium, lanthanum, or iridium [9-16]. These catalysts were characterized by high resistance to deactivation, selectivity towards hydrogen in the range of $60-75 \%$ and content of the CO in the product below $10 \%$. Unfortunately, the level of $\mathrm{CO}$ is too high for an application in fuel cells. Additionally, due to the high production cost of these types of catalysts, many new studies have been conducted to replace them with cheaper ones.

First experiments were carried out on bimetallic systems based on nickel [17-27] and cobalt $[17,20,21,27-30]$, there are also some experiments with copper $[7,17,21,24,31]$ and cerium $[27,32]$ as base metal; the second component was alumina or zirconia. Later, there were attempts on improving activity of bimetallic catalysts by addition of another component. The base component was nickel: $\mathrm{Ni} / \mathrm{CeO}_{2}-\mathrm{Al}_{2} \mathrm{O}_{3}, \mathrm{Ni} / \mathrm{CeO}_{2}-\mathrm{La}_{2} \mathrm{O}_{3}, \mathrm{Ni} / \mathrm{La}_{2} \mathrm{O}_{3}-\mathrm{Al}_{2} \mathrm{O}_{3}, \mathrm{Ni} / \mathrm{La}_{2} \mathrm{O}_{3}-$ $\mathrm{ZrO}_{2}$ [33-35], $\mathrm{Ni}_{0.95} \mathrm{Mo}_{0.05} / \mathrm{SBA}-15$ [36], $\mathrm{Ni} / \mathrm{ZnO} / \mathrm{Al}_{2} \mathrm{O}_{3}$ [37,38], $\mathrm{Ni}_{3} \mathrm{Mg}_{2} / \mathrm{AlO}_{\mathrm{Y}}$ [39], and $\mathrm{Ni}-\mathrm{Cu} / \mathrm{CeMnO}_{2}$ [40]. Dan et al. [33] found that additional oxides of $\mathrm{Ce}$ or $\mathrm{La}$ to $\mathrm{Ni} / \mathrm{Zr}$ and $\mathrm{Ni} / \mathrm{Al}$ catalysts gave a $25-45 \%$ increase in hydrogen yield at temperature of $593 \mathrm{~K}$, and methane was the only byproduct (selectivity above $20 \%$ ). Montero et al. [34], investigating the catalytic system of $\mathrm{Ni} / \mathrm{La}_{2} \mathrm{O}_{3}-\mathrm{Al}_{2} \mathrm{O}_{3}$, found an important increase in hydrogen yield (from $10 \%$ to $90 \%$ ) and lower coking, following increase in temperature (from 873 to $973 \mathrm{~K}$ ). Ladoped ceria-supported nickel catalyst $\mathrm{Ni}-\mathrm{CeLa}_{0.2}$ revealed complete conversion and high $\mathrm{H}_{2}$ production in Xiao et al. [35] investigations, where catalyst was prepared by sol-gel method. In experiments of Kim et al. [36], addition of molybdenum to Ni/SBA-15 catalyst caused an increase in hydrogen selectivity from $65 \%$ to $79 \%$ and prolonged catalyst lifetime. Barroso et al. [37] found that increase in Ni content (from 1 to 25 mass \%) not only increases activity of $\mathrm{Ni} / \mathrm{Zn} / \mathrm{Al}$ catalyst but also increases CO selectivity (from $11 \%$ to $58 \%$ ) at temperature of $773 \mathrm{~K}$. Anjaneyulu et al. [38] experimented with $\mathrm{Zn} / \mathrm{Al}$ ratio (changing it from 1:2 to 2:1) in $\mathrm{Ni} / \mathrm{ZnO} / \mathrm{Al}_{2} \mathrm{O}_{3}$ catalyst and showed better $\mathrm{Ni}$ dispersion and coking resistance for $\mathrm{Zn} / \mathrm{Al}$ ratio 2:1. Very stable catalyst $\mathrm{Ni}_{3} \mathrm{Mg}_{2} / \mathrm{AlO}_{\mathrm{Y}}$, working at very low temperature of $573 \mathrm{~K}$, with about 60\% hydrogen selectivity and lack of CO, was formed by Fang team's [39]. Tricomponent catalysts $\mathrm{Ni} / \mathrm{CeMnO}_{2}$ promoted by $\mathrm{Cu}, \mathrm{Co}, \mathrm{K}$, and Fe were tested by Sohrabi et al. [40]. $\mathrm{Cu}$ addition ( $\mathrm{Ni}-\mathrm{Cu} / \mathrm{CeMnO}_{2}, 5.3-3.6 / 44 / 21$, mass $\%$ ) increased conversion from $57 \%$ to $70 \%$, the highest $\mathrm{H}_{2}$ yield $(60 \%)$ was obtained using Fe addition $\left(\mathrm{Ni}-\mathrm{Fe} / \mathrm{CeMnO}_{2}, 6.3-2.8 / 27 / 26\right)$, but CO level was still high.

There were some works concerning copper-based trimetallic catalysts: $\mathrm{Cu} / \mathrm{Al}_{2} \mathrm{O}_{3} / \mathrm{Mn}$ [41], $\mathrm{CuO} / \mathrm{ZrO}_{2} / \mathrm{Me}(\mathrm{Me}=\mathrm{Ni}, \mathrm{Mn}, \mathrm{Ga})$ [42], $\mathrm{Cu} / \mathrm{Zr} / \mathrm{Ni}$ [24], $\mathrm{Cu} / \mathrm{Ni} / \mathrm{Me}(\mathrm{Me}=\mathrm{Ce}, \mathrm{Nb}, \mathrm{Si})$ [43,44], $\mathrm{Cu} / \mathrm{Ce} / \mathrm{Al}$ [8], and $\mathrm{Cu} / \mathrm{Ce} / \mathrm{Zr}$ [45]. Activity of these types of catalysts was investigated in a wide range of temperatures (573-1073 K) and substrate ratios (ethanol/water ratio equal to 1:30-1:3). According to Das et al. [41], copper-based catalysts, as dehydrogenation catalysts, were most effective for maximizing hydrogen production in ESR process. The team led by Das studied ethanol steam reforming process in the presence of $\mathrm{Cu} / \mathrm{Al}_{2} \mathrm{O}_{3}$ catalysts promoted with manganese. Maximum ethanol conversion of $60.7 \%$ and hydrogen yield of 
$3.74(\mathrm{~mol} \mathrm{H} / 2 / \mathrm{mol}$ ethanol converted) were observed at temperature of $633 \mathrm{~K}$ over catalyst with 2.5 mass\% Mn loading, at ethanol/water ratio equal to 1:6 [41]. Dong et al. [45] investigated the effect of four preparation methods: sol-gel, co-precipitation, one-step impregnation, and two-step impregnation on activity of $\mathrm{Cu} / \mathrm{Ce} / \mathrm{Zr}(1 / 9 / 1$ metal ratio) catalysts in carbon monoxide removal from gas rich in hydrogen. They found the best co-precipitation method, with $\mathrm{Na}_{2} \mathrm{CO}_{3}$ as precipitant, at calcination temperature of $773 \mathrm{~K}$. Śliwa and Samson [42] used $\mathrm{CuO} / \mathrm{ZrO}_{2}$ catalysts doped with $\mathrm{Mn}, \mathrm{Ni}$, or $\mathrm{Ga}$ in ESR process. The reaction parameters were as follows: temperature of $623 \mathrm{~K}$, ethanol/water ratio equal to $1: 10, \mathrm{CuO} / \mathrm{ZrO}_{2}$ ratio equal to $2.3 \mathrm{mass} \% / \mathrm{mass} \%$, and the concentration of dopants was 5 mass $\%$. The maximum hydrogen yield, $52 \%$ of the stoichiometric ethanol efficiency value, was achieved by the addition of nickel. However, it was accompanied with $17 \%$ selectivity to $\mathrm{CO}$. Bergamaschi et al. [24] found that addition of 6 mass $\%$ of nickel to $\mathrm{Cu} / \mathrm{Z} \mathrm{r}$ catalyst increased specific surface area BET and hydrogen selectivity at $573 \mathrm{~K}$. Dancini-Pontes et al. [43] found that $\mathrm{Cu} / \mathrm{Ni} / \mathrm{CeO}_{2}$ catalyst revealed much higher resistance to deactivation and better efficiency at temperature of about $723 \mathrm{~K}$, in comparison with $\mathrm{Cu} / \mathrm{Ni}$ system. The presence of nitrogen in reaction mixture increased hydrogen selectivity of about $20-30 \%$ after $8 \mathrm{~h}$ reaction course at temperature of $723 \mathrm{~K}$. Snytnikov et al. [8] achieved nearly $20 \%$ increase in hydrogen selectivity and only about $2 \% \mathrm{CO}$ content in the product at relatively low temperature of $623 \mathrm{~K}$ by an addition of $\gamma-\mathrm{Al}_{2} \mathrm{O}_{3}$ to $\mathrm{CuO} / \mathrm{CeO}_{2}$ catalyst.

The properties of these catalysts depend mainly not only on their composition, especially on active metal content, but also on the parameters of preparation. Activity and lifetime of a catalyst can be improved by a method of preparation. Chen et al. [44] obtained nearly twice an increase in hydrogen yield by significantly lowering the temperature of reduction with hydrogen (from 923 to $623 \mathrm{~K}$ ) of $\mathrm{CuNi} / \mathrm{SiO}_{2}$ catalyst.

The literature data indicate that improvements in catalyst activity and resistance to deactivation can be achieved by introducing a third component, changing the ratio of individual elements in the catalyst, activation parameters, preparation method, and even the composition of the reaction mixture. However, it is difficult to say which of the catalysts presented in the literature was the best because their activities were usually tested under different, often not fully specified conditions, and their activity parameters were also different.

The aim of the presented work was to obtain an active and selective catalyst for hydrogen production in ethanol steam reforming by introducing $\mathrm{Ni}, \mathrm{Co}$, or Ce additives to a $\mathrm{Cu} / \mathrm{Zr}$ binary catalyst studied previously [17].

\section{Results and Discussion}

\subsection{Characteristics of the Catalysts}

The phase composition of the catalysts after hydrogen reduction was determined by XRD. The XRD patterns ofthe catalysts after hydrogen reduction are presented in Figure 1.

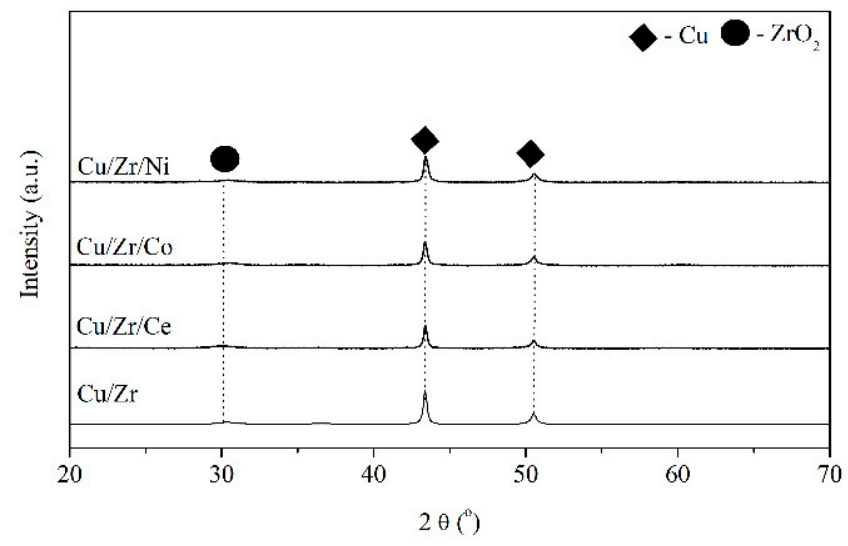

Figure 1. XRD patterns of tested catalysts after hydrogen reduction. 
In the obtained XRD patterns (Figure 1), the $\mathrm{Cu}^{\circ}\left(2 \theta=43,51^{\circ}\right)$ and $\mathrm{ZrO}_{2}\left(2 \theta=30^{\circ}\right)$ phases are present. The intensity of XRD peaks related with metallic copper are higher in comparison with XRD peak assigned to $\mathrm{ZrO}_{2}$. This may be caused by the different concentration of these two phases and differences in the crystallite sizes. On the other hand, there are no XRD peaks related to the $\mathrm{CoO}, \mathrm{NiO}$, and $\mathrm{CeO}_{2}$ phases in the diffractograms. The lack of these signals can be due to high dispersion of additives in the synthesized catalysts. The crystallite sizes calculated by Scherrer method are presented in Table 1.

Table 1. Composition, textural properties, and size of crystallites of tested catalysts.

\begin{tabular}{|c|c|c|c|c|c|c|c|c|c|c|}
\hline \multirow[b]{2}{*}{ Catalyst } & \multirow[b]{2}{*}{$\begin{array}{c}\mathrm{CuO} \\
(\operatorname{mass} \%)\end{array}$} & \multirow[b]{2}{*}{$\begin{array}{c}\mathrm{ZrO}_{2} \\
\text { (mass\%) }\end{array}$} & \multirow{2}{*}{$\begin{array}{l}\text { Other Metal } \\
\text { Oxides } \\
\text { (mass } \% \text { ) }\end{array}$} & \multicolumn{2}{|c|}{ Size of Crystallites ${ }^{b}(\mathrm{~nm})$} & \multirow[b]{2}{*}{$\begin{array}{c}S_{C u}{ }^{c} \\
\left(m^{2} / g_{C u}\right)\end{array}$} & \multirow[b]{2}{*}{$\begin{array}{l}S_{\text {BET }} d \\
\left(\mathrm{~m}^{2} / g\right)\end{array}$} & \multirow[b]{2}{*}{$\begin{array}{c}V_{p} \\
\left(\mathrm{~cm}^{3} / g\right)\end{array}$} & \multirow[b]{2}{*}{$\begin{array}{c}\mathrm{D}_{\mathrm{p}} \\
(\mathrm{nm})\end{array}$} & \multirow[b]{2}{*}{$\begin{array}{c}\mathrm{D}_{\mathrm{Cu}} \\
(\%)\end{array}$} \\
\hline & & & & $\begin{array}{c}\mathrm{Cu}^{0} \\
(\mathbf{1 1 1})\end{array}$ & $\begin{array}{l}\mathrm{ZrO}_{2} \\
(\mathbf{1 1 1})\end{array}$ & & & & & \\
\hline $\mathrm{Cu} / \mathrm{Zr} / \mathrm{Ni}$ & 63.3 & 32.7 & 4 & 37.8 & 6.3 & 13 & 40 & 0.14 & 13 & 2.0 \\
\hline $\mathrm{Cu} / \mathrm{Zr} / \mathrm{Co}$ & 63.3 & 32.7 & 4 & 32.8 & 5.6 & 11 & 32 & 0.12 & 15 & 1.7 \\
\hline $\mathrm{Cu} / \mathrm{Zr} / \mathrm{Ce}$ & 63.3 & 32.7 & 4 & 75.0 & 4.7 & 6 & 35 & 0.13 & 15 & 0.9 \\
\hline $\mathrm{Cu} / \mathrm{Zr}$ & 63.8 & 36.2 & - & 23.1 & 5.5 & 3 & 23 & 0.07 & 13 & 0.5 \\
\hline
\end{tabular}

${ }^{a} \mathrm{Co}_{3} \mathrm{O}_{4}, \mathrm{NiO}$, and $\mathrm{CeO} ;{ }^{b}$ after hydrogen reduction; ${ }^{\mathrm{c}}$ measured by dissociative $\mathrm{N}_{2} \mathrm{O}$ adsorption; ${ }^{\mathrm{d}}$ measured by $\mathrm{N}_{2}$ adsorption at $77 \mathrm{~K}$.

The crystallite sizes of $\mathrm{Cu}^{0}$ are larger than others. Large crystallites of copper revealed low dispersion that ranges from $2 \%$ for $\mathrm{Cu} / \mathrm{Zr} / \mathrm{Ni}$ catalyst and $1.7 \%$ for $\mathrm{Cu} / \mathrm{Zr} / \mathrm{Co}$ to $0.9 \%$ for $\mathrm{Cu} / \mathrm{Zr} / \mathrm{Ce}$ [7].

Experimental adsorption and desorption isotherms of nitrogen $(77 \mathrm{~K})$ are presented in Figure 2a. The investigated catalysts reveal mesopore structure with homogeneous pore distribution, which is characteristic for capillary condensation typical for the mesopore range. This is supported by the shape of the isotherms, which are of type IV (according to IUPAC classification) with hysteresis loops of type $\mathrm{H} 1$ for all tested catalysts (cylindrical pores of almost constant cross-section) (Figure 2a) [46]. Moreover, this is in line with the pore volume distribution profiles exhibiting single narrow peaks with maximum at $4 \mathrm{~nm}$ (Figure 2b).

(a)

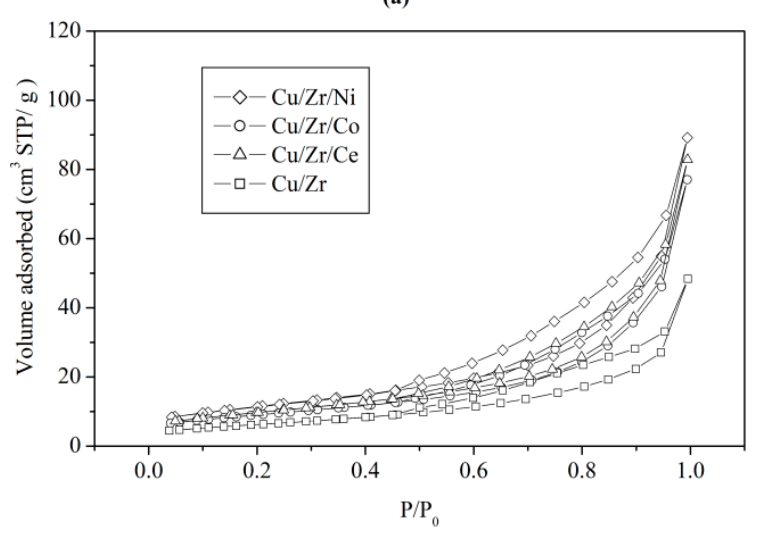

(b)

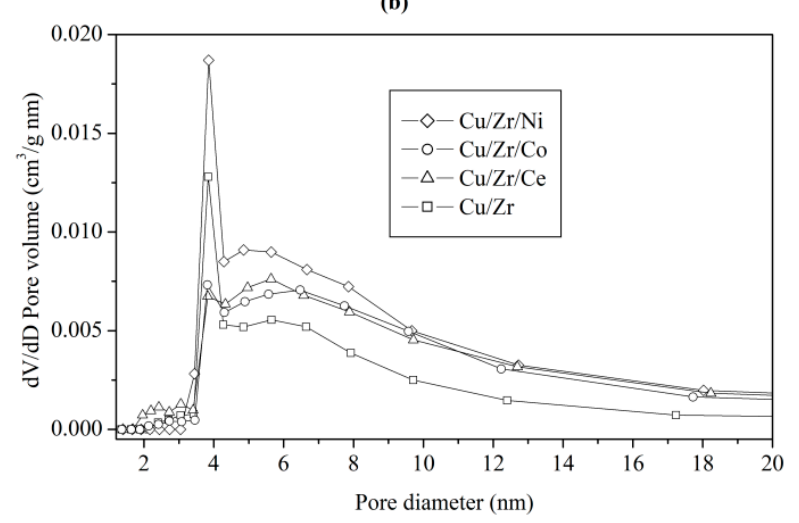

Figure 2. (a) $\mathrm{N}_{2}$ adsorption/desorption isotherms $(77 \mathrm{~K})$ and (b) pore size distribution of the catalysts.

$\mathrm{Cu} / \mathrm{Zr}$ and $\mathrm{Cu} / \mathrm{Zr} / \mathrm{Ni}$ catalysts havemuch more mesoporous structure compared with $\mathrm{Cu} / \mathrm{Zr} / \mathrm{Co}$ and $\mathrm{Ce} / \mathrm{Zr} / \mathrm{Ce}$ catalysts. The copper surface area $\left(\mathrm{S}_{\mathrm{Cu}}\right)$, specific surface area BET $\left(\mathrm{S}_{\mathrm{BET}}\right)$, pore volume $\left(\mathrm{V}_{\mathrm{p}}\right)$, and average pore diameter $\left(\mathrm{D}_{\mathrm{p}}\right)$ are presented in Table 1. An addition of an oxide of $\mathrm{Ce}, \mathrm{Co}$, or $\mathrm{Ni}$ to $\mathrm{Cu} / \mathrm{Zr}$ catalyst results in about 60-70\% increase in $S_{\mathrm{Cu}}$ and $\mathrm{S}_{\mathrm{BET}}$ values followed by $\mathrm{V}_{\mathrm{p}}$ increase in the following order: $\mathrm{Cu} / \mathrm{Zr}<\mathrm{Cu} / \mathrm{Zr} / \mathrm{Co}<\mathrm{Cu} / \mathrm{Zr} / \mathrm{Ce}<\mathrm{Cu} / \mathrm{Zr} / \mathrm{Ni}$. The total pore volume of obtained catalysts reaches about $0.14 \mathrm{~cm}^{3} / \mathrm{g}$.

$\mathrm{H}_{2}-\mathrm{TPR}$ profiles of investigated catalysts are presented in Figure 3. The peaks were observed within the temperature range of 540-583 K. The observed single reduction peak 
refers solely to the reduction of $\mathrm{CuO}$ to $\mathrm{Cu}^{0}$. The addition of $\mathrm{Ni}$ or $\mathrm{Co}$ or $\mathrm{Ce}$ oxides to the $\mathrm{Cu} / \mathrm{Zr}$ catalyst resulted in a $16-40^{\circ}$ decrease in the temperature corresponding to the maximum reduction rate $\left(\mathrm{T}_{\max }\right)$ indicating that the dopants $(\mathrm{Ni}, \mathrm{Co}$ and $\mathrm{Ce})$ facilitate the reduction of $\mathrm{CuO}[47,48]$. An addition of $\mathrm{Co}$ oxide to $\mathrm{Cu} / \mathrm{Zr}$ catalyst causes decrease in the temperature corresponding to maximum reduction $\left(\mathrm{T}_{\max }\right)$ rate by $40 \mathrm{~K}$. Similar effect was observed for others dopants, but in this case, shift in $\mathrm{T}_{\max }$ was only by ca. $20 \mathrm{~K}$.

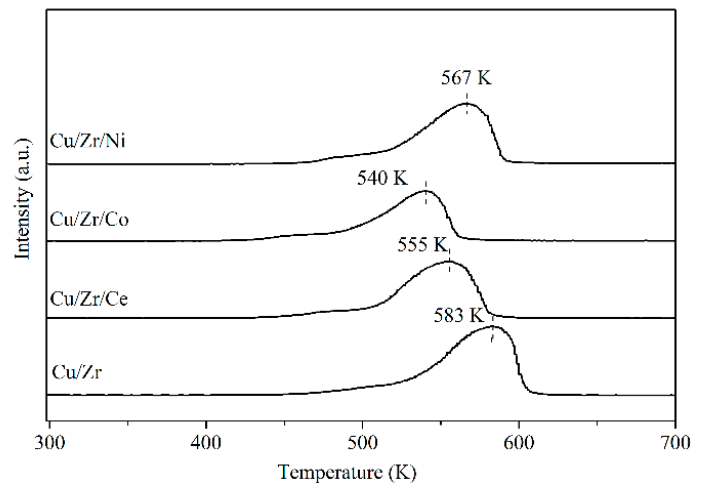

Figure 3. Temperature-programmed reduction of $\mathrm{H}_{2}\left(\mathrm{H}_{2}-\mathrm{TPR}\right)$ profiles of tested catalysts.

The $\mathrm{CO}_{2}$-TPD experiments were performed in order to evaluate the surface basicity of the synthesized catalysts. The recorded TPD profiles (Figure 4) were analyzed in the temperature range corresponding with temperature at which the steam reforming of ethanol reaction had been carried out.

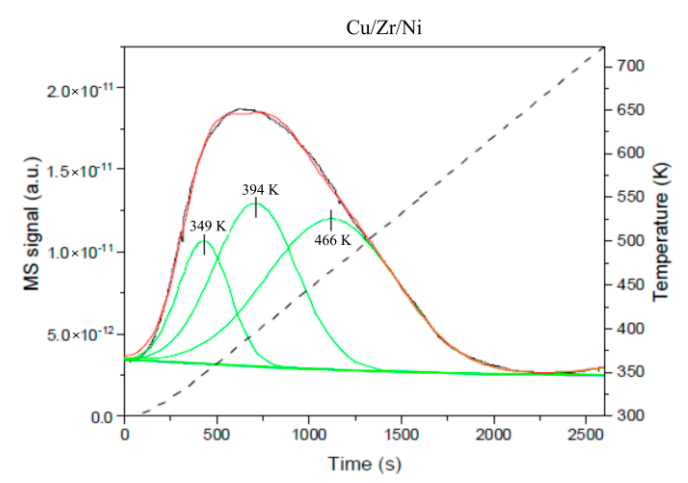

(a)

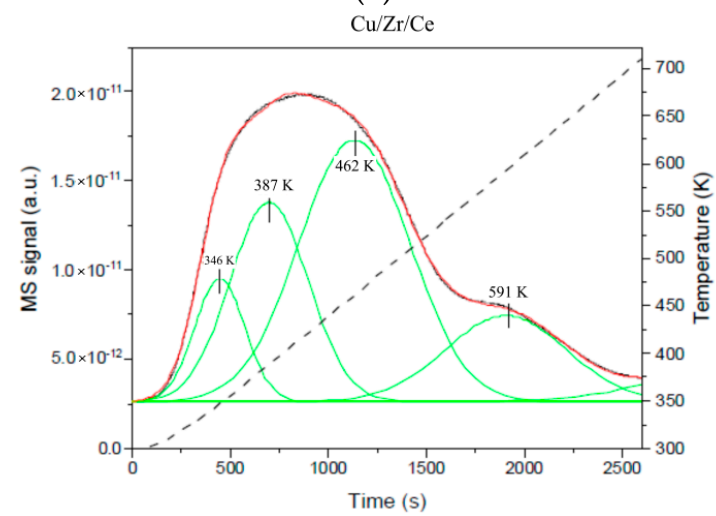

(c)

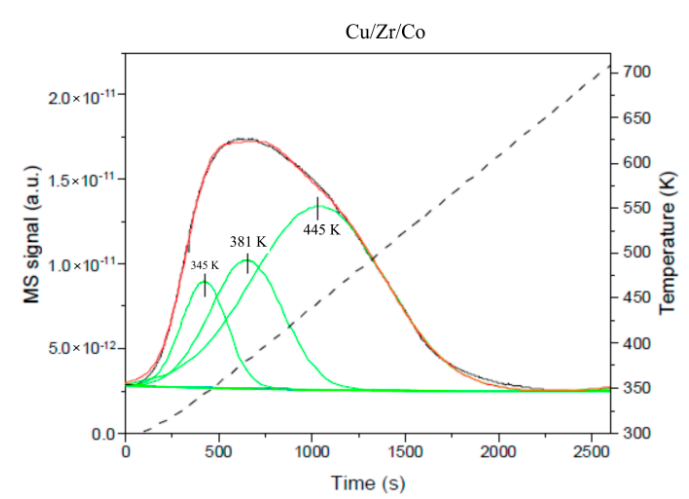

(b)

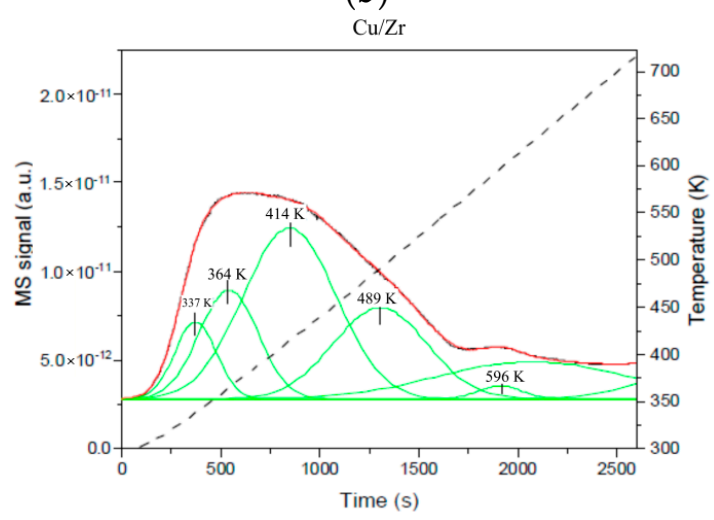

(d)

Figure 4. $\mathrm{CO}_{2}$ temperature-programmed desorption $\left(\mathrm{CO}_{2}-\mathrm{TPD}\right)$ profiles for (a) $\mathrm{Cu} / \mathrm{Zr} / \mathrm{N},(\mathbf{b}) \mathrm{Cu} / \mathrm{Zr} / \mathrm{Co},(\mathbf{c}) \mathrm{Cu} / \mathrm{Zr} / \mathrm{Ce}$ and (d) $\mathrm{Cu} / \mathrm{Zr}$ : signal—black line, cumulative curve—red line, deconvoluted peaks used for quantification-green line, temperature-dashed line. (For interpretation of the references to color in this figure legend, the reader is referred to the Web version of this article). 
For all catalysts, the very broad and complex desorption profile is observed with overlapping signals. In order to get insight in the distribution of weak, medium, and strong basic sites, the TPD profiles were deconvoluted into Gaussian peaks. Based on the maxima position of deconvoluted peaks, signals were assigned accordingly to desorption of $\mathrm{CO}_{2}$ from weak (323-423 K), medium (423-513 K), and strong (>513 K) basic sites. Only deconvoluted maxima up to $623 \mathrm{~K}$ were used for the calculation of basic sites concentration (Table 2), since this was the final calcination temperature of catalysts.

Table 2. Quantitative analysis of basic sites for synthesized catalysts.

\begin{tabular}{ccccccc}
\hline \multirow{2}{*}{ Catalyst } & \multicolumn{3}{c}{ Basic Sites $(\mu \mathrm{mol} / \mathbf{g})$} & $\begin{array}{c}\text { Amount of } \mathbf{C O}_{2} \\
\text { Adsorbed }(\mu \mathrm{mol})\end{array}$ & $\begin{array}{c}\text { Amount of } \mathbf{C O}_{2} \\
\text { Desorbed }(\mu \mathrm{mol})\end{array}$ & $\begin{array}{c}\text { Total Basicity } \\
(\mu \mathrm{mol} / \mathbf{g})\end{array}$ \\
\cline { 2 - 6 } Weak & Medium & Strong & & 3.0 & 79.9 \\
$\mathrm{CuZrNi}$ & 40.4 & 39.6 & - & 3.9 & 3.3 & 67.9 \\
$\mathrm{CuZrCo}$ & 25.1 & 42.8 & - & 5.1 & 4.9 & 96.0 \\
$\mathrm{CuZrCe}$ & 34.2 & 45.4 & 16.4 & 2.9 & 2.8 & 56.2 \\
$\mathrm{CuZr}$ & 41.3 & 13.9 & 1.0 & & & \\
\hline
\end{tabular}

The maxima that were used for quantitative analysis are marked in the TPD profiles. In the case of all catalysts, the amount of adsorbed $\mathrm{CO}_{2}$ and desorbed $\mathrm{CO}_{2}$ during TPD experiments is the same, meaning that the entire $\mathrm{CO}_{2}$ was desorbed during TPD runs in the analyzed temperature range. According to quantitative results (Table 2), the lowest concentration of basic sites is observed for $\mathrm{Cu} / \mathrm{Zr}(56.2 \mu \mathrm{mol} / \mathrm{g})$. In the case of this catalyst, the contribution of weak basic sites in total basicity is the highest among synthesized samples $(41.3 \mu \mathrm{mol} / \mathrm{g})$. On the other hand, the modification of $\mathrm{Cu} / \mathrm{Zr}$ catalysts with dopants leads to increase in total surface basicity in the following order of $\mathrm{Cu} / \mathrm{Zr} / \mathrm{Co}<\mathrm{Cu} / \mathrm{Zr} / \mathrm{Ni}<\mathrm{Cu} / \mathrm{Zr} / \mathrm{Ce}$. According to literature $[49,50]$ weak basic sites can be related with surface hydroxyl group, medium basic sites with $\mathrm{Zr}^{4+-} \mathrm{O}^{2-}$ pairs, and the strong basic sites with the low-coordination oxygen anions.

Additionally, the distribution of basic sites for modified catalysts changes in comparison with $\mathrm{Cu} / \mathrm{Zr}$. The decrease in concentration of weak basic sites is visible upon catalyst modification with $\mathrm{Co}$ and $\mathrm{Ce}$, whereas concentration of weak basic sites decreases. Moreover, in the case of $\mathrm{Cu} / \mathrm{Zr} / \mathrm{Ce}$, strong basic sites are generated $(16.4 \mu \mathrm{mol} / \mathrm{g})$. For catalyst doped with $\mathrm{Ni}$, the amount of medium basic sites is higher when compared with $\mathrm{Cu} / \mathrm{Zr}$ but there is no change in concentration of weak basic sites.

\subsection{Catalytic Activity}

Catalytic activity results are graphically presented in Figures 5-8.

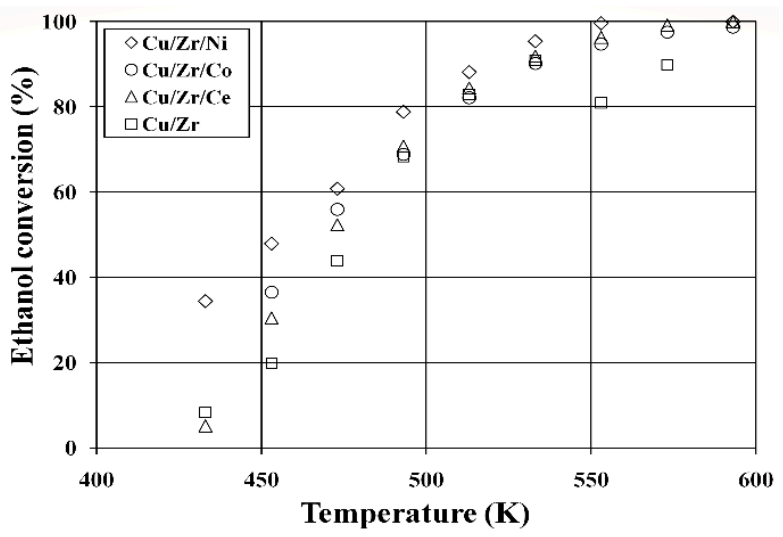

Figure 5. The effect of temperature on ethanol conversion in ethanol steam reforming (ESR) over tested catalysts. 


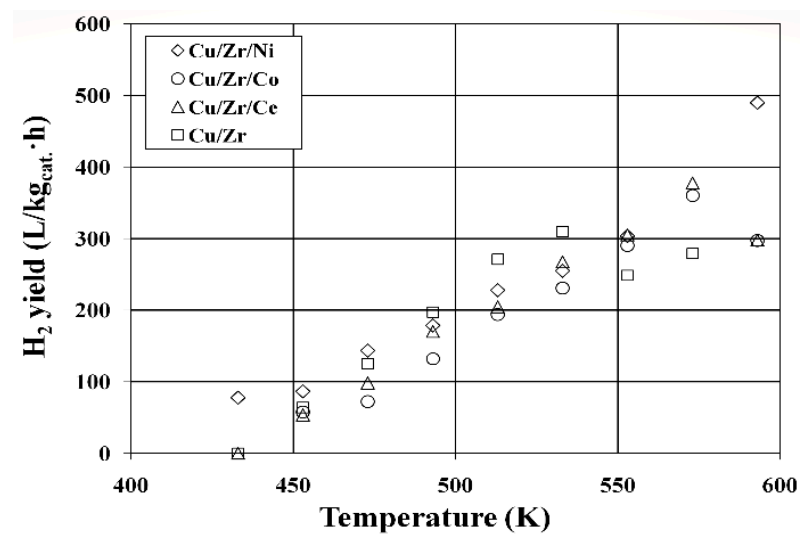

Figure 6. The effect of temperature on $\mathrm{H}_{2}$ yield in ESR over tested catalysts.

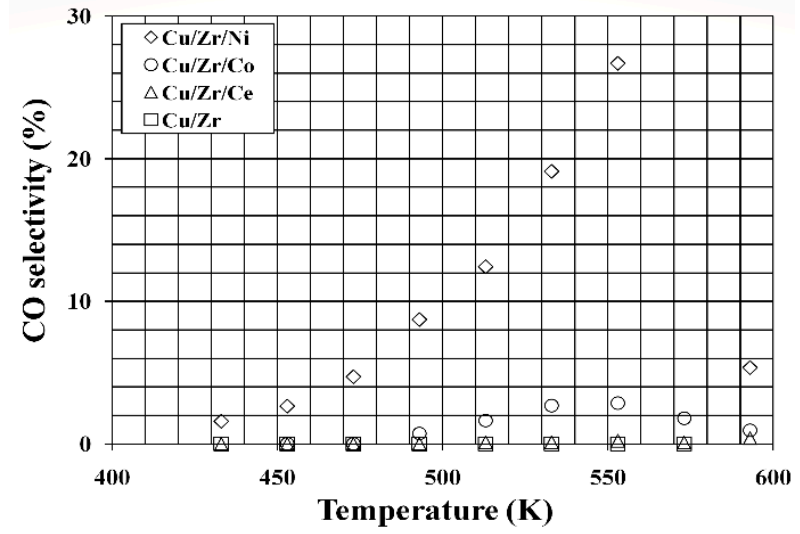

Figure 7. The effect of temperature on CO selectivity in ESR over tested catalysts.

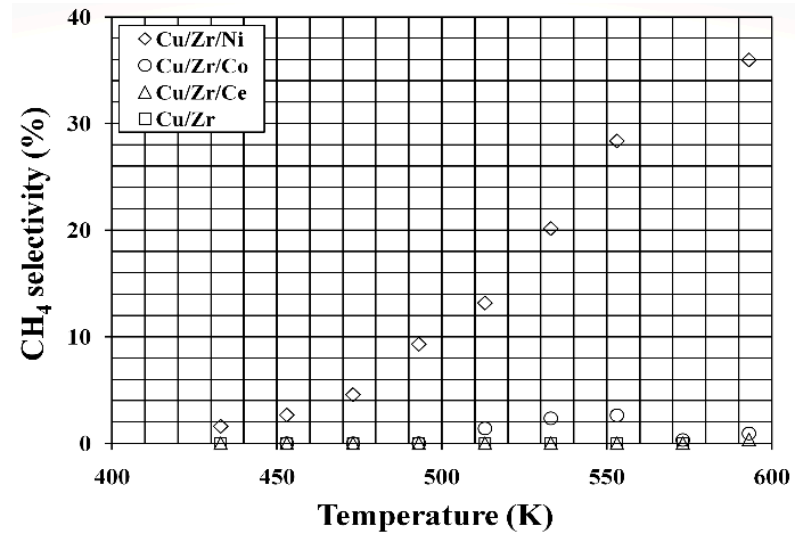

Figure 8. The effect of temperature on $\mathrm{CH}_{4}$ selectivity in ESR over tested catalysts.

All modified catalysts reached about 100\% conversion of ethanol (see Figure 5), a slightly higher than basic $\mathrm{Cu} / \mathrm{Zr}$ catalyst ( $\sim 90 \%$ conversion). The temperature effected the hydrogen yield (see Figure 6) in similar way up to temperature of $550 \mathrm{~K}$, giving the value of $300 \mathrm{~L} /\left(\mathrm{kg}_{\text {cat. }} \cdot \mathrm{h}\right)$. In the presence of $\mathrm{Cu} / \mathrm{Zr} / \mathrm{Ni}$ catalyst, further increase in temperature caused the highest increase in hydrogen yield, resulting inthe value of $490 \mathrm{~L} /\left(\mathrm{kg}_{\text {cat. }} \cdot \mathrm{h}\right)$ (Table 3); unfortunately accompanied by high production of carbon monoxide (see Figure 7 , Table 3), harmful for fuel cells-27\% selectivity at $553 \mathrm{~K}$ and rapid decrease to $6 \%$ selectivity at $593 \mathrm{~K}$. The methane selectivity also reached high value of $36 \%$ at $593 \mathrm{~K}$ (see Figure 8 and Table 3), but it is not harmful, methane could potentially be used as a source of energy in this endothermic ethanol steam reforming process. 
Table 3. Maximum hydrogen yield at corresponding temperature for tested catalysts.

\begin{tabular}{cccccc}
\hline Catalyst & $\begin{array}{c}\mathbf{W}_{\mathbf{H}_{2}}^{\max } \\
\left(\mathbf{L} / \mathbf{k g} \mathbf{g}_{\text {cat }} \cdot \mathbf{h}\right)\end{array}$ & $\begin{array}{c}\mathbf{T} \\
\mathbf{( K )}\end{array}$ & $\begin{array}{c}\boldsymbol{\alpha} \\
\mathbf{( \% )}\end{array}$ & $\begin{array}{c}\mathbf{S}_{\mathrm{CO}} \\
\mathbf{( \% )}\end{array}$ & $\begin{array}{c}\mathbf{S}_{\mathbf{C H}_{4}} \\
\mathbf{( \% )}\end{array}$ \\
\hline $\mathrm{Cu} / \mathrm{Zr} / \mathrm{Ni}$ & 490 & 593 & 100 & 5.3 & 35.9 \\
$\mathrm{Cu} / \mathrm{Zr} / \mathrm{Co}$ & 360 & 573 & 97 & 1.8 & 0.3 \\
$\mathrm{Cu} / \mathrm{Zr} / \mathrm{Ce}$ & 378 & 573 & 99 & 0.1 & 0.0 \\
$\mathrm{Cu} / \mathrm{Zr}$ & 309 & 533 & 91 & 0.0 & 0.0 \\
\hline
\end{tabular}

$\mathrm{Cu} / \mathrm{Zr} / \mathrm{Co}$ and $\mathrm{Cu} / \mathrm{Zr} / \mathrm{Ce}$ catalysts revealed similar properties. The hydrogen yield reached similar values, with maximum of about $380 \mathrm{~L} /\left(\mathrm{kg}_{\text {cat. }} . \mathrm{h}\right.$ ) at $573 \mathrm{~K}$ (Table 3). Selectivity towards carbon monoxide was low, with a maximum of $3 \%$ at $553 \mathrm{~K}$ for $\mathrm{Cu} / \mathrm{Zr} / \mathrm{Co}$ catalyst; very low value, below $0.5 \%$ for $\mathrm{Cu} / \mathrm{Zr} / \mathrm{Ce}$ catalyst. Baneshi et al. [51] also confirmed such a good selectivity of the cerium-containing catalyst. Methane was not detected in the course of reaction in the presence of $\mathrm{Cu} / \mathrm{Zr} / \mathrm{Ce}$ catalyst, whereas in the presence of $\mathrm{Cu} / \mathrm{Zr} / \mathrm{Co}$ catalyst, it was $3 \%$ at temperature of $553 \mathrm{~K}$.

The $\mathrm{Cu} / \mathrm{Zr} / \mathrm{Ni}$ catalyst, which has the highest value of $\mathrm{S}_{\mathrm{Cu}}\left(13 \mathrm{~m}^{2} / \mathrm{g}_{\mathrm{Cu}}\right), \mathrm{D}_{\mathrm{Cu}}(2 \%)$, and $\mathrm{S}_{\mathrm{BET}}\left(40 \mathrm{~m}^{2} / \mathrm{g}\right)$, exhibited the highest yield to hydrogen $\left(490 \mathrm{~L} /\left(\mathrm{kg}_{\text {cat. }} \cdot \mathrm{h}\right)\right.$. On the other hand, $\mathrm{Cu} / \mathrm{Zr} / \mathrm{Co}$ catalyst, whosephysicochemical properties are close to $\mathrm{Cu} / \mathrm{Zr} / \mathrm{Ni}$ catalyst, yields the lower value of hydrogen (about $300 \mathrm{~L} /\left(\mathrm{kg}_{\text {cat. }} \cdot \mathrm{h}\right.$ ), similar to $\mathrm{Cu} / \mathrm{Zr} / \mathrm{Ce}$ (Table 1 and Figure 7).

According to XRD analysis, the $\mathrm{Cu} / \mathrm{Zr} / \mathrm{Co}$ catalyst has large $\mathrm{CuO}$ crystallites and the smallest $\mathrm{ZrO}_{2}$ crystallites. This is in agreement with the chemisorption of $\mathrm{N}_{2} \mathrm{O}$, which showed that the $\mathrm{Cu} / \mathrm{Zr} / \mathrm{Ce}$ catalyst has low value of metallic copper dispersion and metallic coppers surface area (Table 1 ) resulting from agglomeration of copper crystallite. This can lead to lower hydrogen yield [52]. Additionally, similar value of hydrogen yield is observed for $\mathrm{Cu} / \mathrm{Zr} / \mathrm{Co}$ catalyst, having the same average pore diameter as $\mathrm{Cu} / \mathrm{Zr} / \mathrm{Ce}$ catalyst. Mastalir et al. [53] in their investigation on methanol steam reforming found that the changes of copper concentration in $\mathrm{Cu} / \mathrm{Ce} / \mathrm{Zr}$ catalyst resulted in altering the microstructure of the $\mathrm{Cu}$ particles. An increase in $\mathrm{Cu}$ concentration from 5 to $35 \mathrm{wt} \%$, at a constant $\mathrm{ZrO}_{2} / \mathrm{CeO}_{2}$ molar ratio of $1 / 1$, resulted in an increase in crystallite size and consequently a decrease in the specific surface area of the active particles and a significant inhibition of CO production.

The increase in the hydrogen yield for modified catalysts can results from higher surface basicity of these catalysts. This is due to the fact that surface sites of higher basicity catalyze the reaction of ethanol dehydrogenation to acetaldehyde (2) [54,55].

During ethanol steam reforming, different types of carbon are being deposited on the catalyst surface, which is one of the reasons for catalyst deactivation [26,56]. This is strongly related with the reaction conditions and used catalysts. According to literature, carbon is formed during Boudouard reaction and dissociation of hydrocarbons molecules [57]. Various forms of carbon can be identified by peak positions in TPO profiles since amorphous carbon is oxidized at low temperature, whereas filamentous carbon undergoes oxidation at higher temperature ( $>823 \mathrm{~K}$ ) [58]. The recorded TPO profiles are depicted in Figure 9. Based on the position of peak maxima (502-663 K), it can be stated that carbon deposit is in the amorphous state in the case of all catalysts [59].

In TPO profile for $\mathrm{Cu} / \mathrm{Zr}$, two separated $\mathrm{CO}_{2}$ peaks of very small intensity can be visible with the maximum at 502 and $576 \mathrm{~K}$. The amount of calculated carbon deposit is the smallest among spent catalyst and equal to $16.4 \mathrm{C}_{\mathrm{S}} \mathrm{mg} / \mathrm{g}$. The first peak of $\mathrm{CO}_{2}$ is accompanied by peak of $\mathrm{H}_{2} \mathrm{O}$, which is formed during oxidation (maximum at $507 \mathrm{~K}$ ). The presence of water during oxidation suggests that carbon deposit contains also hydrogen. On the other hand, oxidation of remaining intermediates $\left(\mathrm{C}_{x} \mathrm{H}_{y} \mathrm{O}_{z}\right)$, formed during ESR reaction, cannot be excluded since the temperature of oxidation is low [60]. The very low concentration of carbon for $\mathrm{Cu} / \mathrm{Zr}$ catalyst results from its low activity in ethanol steam reforming. Similarly, water peak is observed for $\mathrm{Cu} / \mathrm{Zr} / \mathrm{Ce}$ catalyst but signal is shifted to higher temperature $(557 \mathrm{~K})$ and is of higher intensity in comparison with unmodified 
catalyst. This is also valid for $\mathrm{CO}_{2}$ signal with the maximum at $550 \mathrm{~K}$. The increase in temperature of surface carbon oxidation is due to stronger carbon interaction with catalyst surface. The amount of carbon deposit is $79.5 \mathrm{mg} \mathrm{C}_{\mathrm{s}} / \mathrm{g}$, which is the highest recorded value among spent catalysts. The decrease in concentration of carbon deposit $\left(63.0 \mathrm{mg} \mathrm{C}_{\mathrm{s}} / \mathrm{g}\right) \mathrm{can}$ be stated for $\mathrm{Cu} / \mathrm{Zr} / \mathrm{Ni}$ in comparison with $\mathrm{Cu} / \mathrm{Zr} / \mathrm{Ce}$. In this case, there is also fraction of carbon that contains hydrogen since the peak of water during oxidation is present (569 K). Further shift of $\mathrm{CO}_{2}$ peak toward higher temperature is visible in the case of $\mathrm{Cu} / \mathrm{Zr} / \mathrm{Co}$ catalyst. In the TPO profile of this catalyst, there are two separated $\mathrm{CO}_{2}$ peaks at 579 and $663 \mathrm{~K}$. Based on these two signals, the calculated concentration of surface carbon is equal to $49.1 \mathrm{mg} \mathrm{C} / \mathrm{g}$. Moreover, the absence of $\mathrm{H}_{2} \mathrm{O}$ peaks proves that carbon deposit does not contain hydrogen and there is no oxidation of surface intermediates. For this catalyst, oxidation of carbon, which is formed on the surface during ethanol steam reforming, is hindered since $\mathrm{CO}_{2}$ peaks emerge at the highest temperature when compared with the rest of spent catalysts.

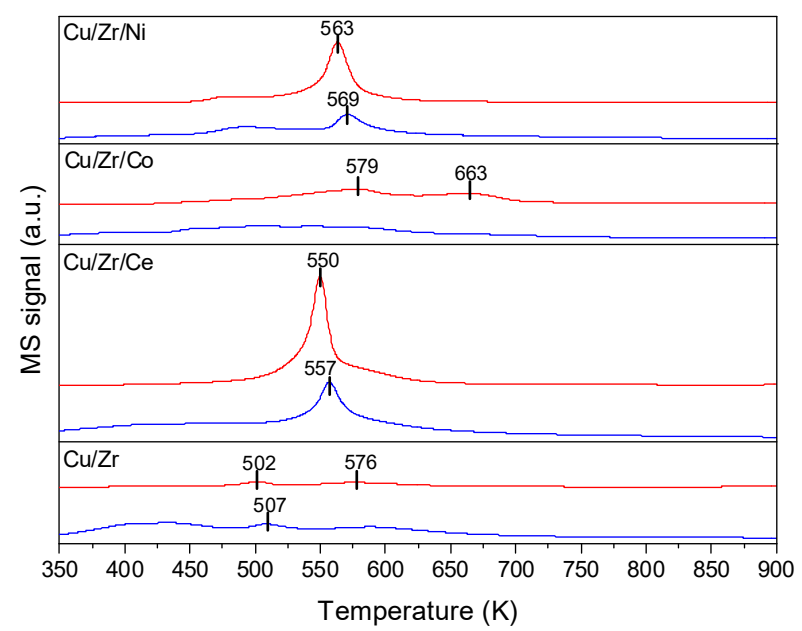

Figure 9. TPO profiles for spent catalysts: $\mathrm{CO}_{2}$-red line and $\mathrm{H}_{2} \mathrm{O}-$ blue line (signal multiplied by factor of 8).

The clear correlation between hydrogen yield and BET surface area or copper dispersion was not found.

\section{Materials and Methods}

\subsection{Materials}

For the synthesis of catalysts, $\mathrm{Ni}\left(\mathrm{NO}_{3}\right)_{2} \cdot 6 \mathrm{H}_{2} \mathrm{O}, \mathrm{Co}\left(\mathrm{NO}_{3}\right)_{2} \cdot 6 \mathrm{H}_{2} \mathrm{O}, \mathrm{Cu}\left(\mathrm{NO}_{3}\right)_{2} \cdot 3 \mathrm{H}_{2} \mathrm{O}$, $\mathrm{Ce}\left(\mathrm{NO}_{3}\right)_{3} \cdot 6 \mathrm{H}_{2} \mathrm{O}$, and $\mathrm{ZrO}\left(\mathrm{NO}_{3}\right)_{2} \cdot \mathrm{H}_{2} \mathrm{O}$ were purchased from Sigma-Aldrich USA (St. Louis, MO, USA); citric acid monohydrate was purchased from Stanlab Sp.j. Poland; and 65 mass $\%$ nitric acid was purchased from Avantor Performance Materials Poland; all the compounds and reagents were of AR grade. To determine the catalyst activity, ethanol of purity spectrophotometric grade, purchased from Merck KGaA was used.

\subsection{Catalysts Preparation}

All precursors of $\mathrm{Cu}, \mathrm{Zr}, \mathrm{Co}, \mathrm{Ni}$, and Ce catalysts-oxides-have been prepared according to the method of thermal decomposition of organic complexes containing metallic components of catalyst [61]. Stoichiometric amounts of nitrates of $\mathrm{Cu}, \mathrm{Zr}, \mathrm{Co}, \mathrm{Ni}$, and $\mathrm{Ce}$ were carefully added, thoroughly stirred, to the solution of citric acid (concentration of $2 \mathrm{~mol} / \mathrm{dm}^{3}+2 \%$ excess). Then, the mixture was evaporated in a rotary vacuum evaporator in temperature of $363 \mathrm{~K}$ for around $24 \mathrm{~h}$. The precipitate of formed citrates was carefully oxidized to prevent local overheating and explosive course of the oxidation reaction (temperature program: $360 \mathrm{~K}, 0.1 \mathrm{~K} / \mathrm{min} ; 403 \mathrm{~K}$ ). The formed mixture of oxides was 
calcined in a muffle with access of air (temperature program: $373,473,523,573$, and $623 \mathrm{~K}$ during $1 \mathrm{~h}$ ).

The reason we used this method is perfectly mixed components thanks to the branched structure of citrates and consequentlyexcellent homogeneity and fully repeatable properties of the prepared catalyst [62]. The conventional method of co-precipitation did not provide such results, although it is usually used, as it is described in the literature.

The last stages of preparation were pelletizing the resulting powder, crushing, and sizing (0.8-1 mm grain). In all obtained catalysts, the ratio of respective metals was about $63 / 34 / 4(\mathrm{mass} \% / \mathrm{mass} \% /$ mass $\%)$. The composition of the reference $\mathrm{Cu} / \mathrm{Zr}$ catalyst was equal to $63.8 / 36.2$ (mass\%/mass\%) (Table 1 ).

\subsection{Catalysts Characterization}

Phase analysis based on the X-ray powder diffraction (XRD) measurements was performed on a X'PERT PRO MDP diffractometer with the X'CELERATOR detector, working in Bragg-Brentano geometry. The XRD measurements (at $40 \mathrm{kV}$ and $30 \mathrm{~mA}$ ) were performed in the $2 \theta$ range from $5^{\circ}$ to $90^{\circ}$ with the interpolated step size $0.02^{\circ}$. The crystallite sizes were calculated from Scherrer method. The XRD phase analysis was performed using reference standards from the International Centre for Diffraction Data (ICDD) PDF-4 database.

The BET surface area was measured with nitrogen adsorption at $77 \mathrm{~K}$ using Quantachrome Autosorb-1. Prior to the measurements, samples were preheated and degassed under vacuum at $373 \mathrm{~K}$ for $18 \mathrm{~h}$. The pores size distribution profiles were obtained by Barrett-Joyner-Halenda (BJH) method from a desorption branch. The micropore area was obtained by V-t plot method.

The active surface of copper $\left(\mathrm{S}_{\mathrm{Cu}}\right)$ in the reduced catalyst was determined with the use of reactive adsorption of $\mathrm{N}_{2} \mathrm{O}$ at $363 \mathrm{~K}$ (VG/Fisons Quartz 200D)according to the method described in [63]. It has been assumed in calculations that the reoxidation of surface copper follows the chemical equation: $2 \mathrm{Cu}(\mathrm{s})+\mathrm{N}_{2} \mathrm{O}(\mathrm{g}) \rightarrow \mathrm{Cu}_{2} \mathrm{O}(\mathrm{s})+\mathrm{N}_{2}(\mathrm{~g})$ and that $1 \mathrm{~m}^{2}$ of elemental copper corresponds to $6.1 \mu \mathrm{mol}$ of $\mathrm{O}_{2}$.

The $\mathrm{H}_{2}$-TPR (temperature-programmed reduction of $\mathrm{H}_{2}$ ) measurements were performed in ChemBED-3000 (Quantachrome) $\mathrm{u}$-shape quartz flow reactor (diameter ca. $5 \mathrm{~mm}$ ) at temperature range of 300-1050 K with temperature ramp of $10 \mathrm{~K} / \mathrm{min}$ and a flow rate of $5 \% \mathrm{H}_{2}$ in Ar. Before the TPR analysis, all samples were kept in a stream of helium at $373 \mathrm{~K}$ for $1.5 \mathrm{~h}$ to remove physically adsorbed water.

The $\mathrm{CO}_{2}$-TPD $\left(\mathrm{CO}_{2}\right.$ temperature-programmed desorption) measurements were carried out in quartz fixed-bed flow reactor connected online to mass spectrometer (QMG 220 PRISMA PLUS). Prior to TPD run, sample $(50 \mathrm{mg})$ was reduced in $5 \% \mathrm{H}_{2} / \mathrm{Ar}$ flow at $723 \mathrm{~K}$ for $1 \mathrm{~h}$. Next, reactor was cooled down to room temperature (RT) and pulses $(250 \mu \mathrm{L})$ of $5 \% \mathrm{CO}_{2} / \mathrm{Ar}$ were introduced until saturation. Then, sample was flashed with $\mathrm{He}$ flow $(40 \mathrm{~mL} / \mathrm{min})$ for $0.5 \mathrm{~h}$ until obtaining stable $\mathrm{CO}_{2}$ line $(\mathrm{m} / \mathrm{z}=44)$. TPD was done from RT to $973 \mathrm{~K}$ with $\Delta \mathrm{T}=10 \mathrm{~K} / \mathrm{min}$ under He flow.

The TPO (temperature-programmed oxidation measurements) of spent catalysts were performed using the same set-up line as for $\mathrm{CO}_{2}$-TPD. For typical TPO run, $20 \mathrm{mg}$ of sample was put in the reactor. Next, sample was oxidized in the stream of $5 \% \mathrm{O}_{2} / \mathrm{He}(30 \mathrm{~mL} / \mathrm{min})$ in the temperature range of RT-900 K. The following signals $(\mathrm{m} / \mathrm{z})$ were monitored with QMS during TPO: $18\left(\mathrm{H}_{2} \mathrm{O}\right), 32\left(\mathrm{O}_{2}\right)$, and $44\left(\mathrm{CO}_{2}\right)$. The amount of deposited carbon $\left(\mathrm{C}_{\mathrm{s}}\right)$ was calculated for spent catalysts after time on stream $=50 \mathrm{~h}$. It was assumed that entire carbon undergoes oxidation during TPO according to the following chemical equation: $\mathrm{C}_{\mathrm{s}}+\mathrm{O}_{2}=\mathrm{CO}_{2}$. The oxidation of fraction of carbon thatcontained hydrogen was not taken into consideration. The calibration of $\mathrm{CO}_{2}$ mass spectrometer signal was performed by injecting pulses of $5 \% \mathrm{CO}_{2} / \mathrm{He}$ with sampling loop of $250 \mu \mathrm{L}$.

\subsection{Catalytic Tests}

Catalytic experiments were performed in the continuous flow fixed-bed reactor of $8 \mathrm{~cm}^{3}$ volume, made of stainless steel. To obtain the active form, the catalyst sample of $2 \mathrm{~g}$ 
was reduced in a stream of diluted hydrogen $\left(7\right.$ vol. $\% \mathrm{H}_{2}$ in $\left.\mathrm{N}_{2}\right)$ at temperature of $723 \mathrm{~K}$ at atmospheric pressure and stabilized in the mixture of reactants (temperature program: $443 \mathrm{~K}, 1.5 \mathrm{~K} / \mathrm{min} ; 553 \mathrm{~K}$ for $4 \mathrm{~h}$ ). This procedure was repeated until the hydrogen yield was constant. Testing parameters were temperature range dependent on respective catalyst activity of $433-593 \mathrm{~K}$, the reactant flow of $100 \mathrm{~mL} / \mathrm{min}$, and ethanol to water initial molar ratio of 1:3 in the stream of pure $\mathrm{N}_{2}$. Previously, the feed nitrogen was deoxidized with the BTS deoxidizer and dehydrated with the molecular sieve of $5 \AA$. The inlet and outlet gases were directed on-line to the gas chromatograph VARIAN STAR 3800. The gaseous products were analyzed in the system of Carbo Plot P7 column $(25 \mathrm{~m} \times 0.53 \mathrm{~mm})$ and Supelcowax 10 column $(30 \mathrm{~m} \times 0.32 \mathrm{~mm})$. Ethanol was determined quantitatively in the Supelcowax 10 column and FID detector, and the remaining gases were determined in the Carbo Plot P7 column and TCD detector. Additionally, carbon monoxide and methane were determined quantitatively in the methanizer with the sensitivity of $20 \mathrm{ppb}$.

Activity of tested catalysts was characterized by hydrogen yield, ethanol conversion, and selectivities of carbon monoxide and methane according to formulas given below [64]:

$$
\begin{aligned}
& \mathrm{W}_{\mathrm{H}_{2}}=\frac{\mathrm{V}_{\mathrm{H}_{2}}}{\mathrm{~m}_{\text {cat. }}}, \quad\left(\mathrm{L} / \mathrm{kg}_{\text {cat. }} \cdot \mathrm{h}\right) \\
& \alpha=\frac{\mathrm{F}_{\mathrm{EtOH}}^{\text {in }}-\mathrm{F}_{\mathrm{EtOH}}^{\mathrm{out}}}{\mathrm{F}_{\mathrm{EtOH}}^{\text {in }}} 100, \quad(\%) \\
& S_{i}=\frac{F_{i}^{\text {out }}}{2\left(\mathrm{~F}_{\mathrm{EtOH}}^{\text {in }}-\mathrm{F}_{\mathrm{EtOH}}^{\text {out }}\right)} 100,(\%) \text {, }
\end{aligned}
$$

where $\mathrm{m}_{\text {cat. }}(\mathrm{g})$ - catalyst mass, $\mathrm{V}_{\mathrm{H}_{2}}(\mathrm{~L} / \mathrm{h})$ - -volume flow rate of hydrogen, $\mathrm{F}_{\mathrm{i}}^{\text {in }}$ and $\mathrm{F}_{\mathrm{i}}^{\text {out }}$ $(\mathrm{mol} / \mathrm{h})$-molar flow rate of $i$-th component at input and output $\left(\mathrm{CO}, \mathrm{CH}_{4}\right)$, respectively, and $\mathrm{EtOH}$ - ethanol.

\section{Conclusions}

The investigations on activity of tricomponent copper-based catalysts have been conducted, focusing on those applied in the ethanol steam reforming process. The properties of these catalysts were compared with those of the tested bicomponent $\mathrm{Cu} / \mathrm{Zr}$ catalyst and prepared according to the same procedure. Relatively low reaction temperature using copper-based catalysts and very low value of carbon monoxide selectivity are important advantages. The disadvantage was not of sufficient value for hydrogen yield.

Among investigated $\mathrm{Cu} / \mathrm{Zr} / \mathrm{Co}, \mathrm{Cu} / \mathrm{Zr} / \mathrm{Ni}$, and $\mathrm{Cu} / \mathrm{Zr} / \mathrm{Ce}$, the best performance was achieved for $\mathrm{Cu} / \mathrm{Zr} / \mathrm{Ce}$ catalyst. A hydrogen yield of $400 \mathrm{~L} /\left(\mathrm{kg}_{\text {cat. }} \cdot \mathrm{h}\right)$ with ethanol conversion close to $100 \%$ with the lowest selectivity towards CO was obtained in the presence of this catalyst at $573 \mathrm{~K}$. It must be highlighted that the selectivity towards carbon monoxide was below a value of $0.5 \%$, required for use in fuel cells.

The addition of nickel to the $\mathrm{Cu} / \mathrm{Zr}$ catalyst improved hydrogen yield to the highest value of $500 \mathrm{~L} /\left(\mathrm{kg}_{\text {cat. }} \cdot \mathrm{h}\right)$, but unfortunately it generates large amounts of carbon monoxide (selectivity reached 27\%) and methane (selectivity reached 36\%). The addition of cobalt to the $\mathrm{Cu} / \mathrm{Zr}$ catalyst caused increase in hydrogen yield similarly to that caused by the cerium addition. However, selectivity towards carbon monoxide was higher.

Further investigations on the application of $\mathrm{Cu} / \mathrm{Zr} / \mathrm{Ce}$ catalyst in the ethanol steam reforming process should be focused to wider analyses of the role and concentration of cerium.

Author Contributions: Conceptualization, M.M.-L. and Ł.H.; methodology, M.M.-L.; investigation, Ł.H., M.Ś., K.S. and M.R.-M.; data curation, Ł.H., M.M.-L., M.K., M.Ś., K.S. and M.R.-M.; writingoriginal draft preparation, Ł.H., M.M.-L., M.K.; writing-review and editing, Ł.H., M.M.-L., M.K., M.Ś.; supervision, M.M.-L., M.K. All authors have read and agreed to the published version of the manuscript. 
Funding: The work was in part supported by National Science Center within the project SONATA, No: 2016/23/D/ST4/02492, 2017-2020 (M.Ś).

Data Availability Statement: Institute of Chemical Engineering, Polish Academy of Sciences, 5 Bałtycka Street, 44-100 Gliwice, Poland and Jerzy Haber Institute of Catalysis and Surface Chemistry, Polish Academy of Sciences, 8 Niezapominajek Street, 30-239 Krakow, Poland.

Conflicts of Interest: The authors declare no conflict of interest.

\section{References}

1. Ogo, S.; Sekine, Y. Recent progress in ethanol steam reforming using non-noble transition metal catalysts: A review. Fuel Process. Technol. 2020, 199, 106238-106249. [CrossRef]

2. Gonzalez-Gil, R.; Chamorro-Burgos, I.; Herrera, C.; Larrubia, M.A.; Laborde, M.; Marino, F.; Alemany, L.J. Production of hydrogen by catalytic steam reforming of oxygenated model compounds on Ni-modified supported catalysts. Simulation and experimental study. Int. J. Hydrogen Energy 2015, 40, 11217-11227. [CrossRef]

3. Madej-Lachowska, M.; Kulawska, M.; Słoczyński, J. Methanol as a high purity hydrogen source for fuel cells: A brief review of catalysts and rate expressions. Chem. Proc. Eng. 2017, 38, 147-162. [CrossRef]

4. Rashid, M.M.; Al Mesfer, M.K.; Naseem, H.; Danish, M. Hydrogen Production by Water Electrolysis: A Review of Alkaline Water Electrolysis, PEM Water Electrolysis and High Temperature Water Electrolysis. Int. J. Eng. Adv. Technol. 2015, 4, 80-93.

5. Luo, M.; Yi, Y.; Wang, S.; Wang, Z.; Du, M.; Pan, J.; Wang, Q. Review of hydrogen production using chemical-looping technology. Renew. Sust. Energy Rev. 2018, 81, 3186-3214. [CrossRef]

6. Li, Y.; Zhang, Z.; Jia, P.; Dong, D.; Wang, Y.; Hu, S.; Xiang, J.; Liu, Q.; Hu, X. Ethanol steam reforming over cobalt catalysts: Effect of a range of additives on the catalytic behaviors. J. Energy Inst. 2020, 93, 165-184. [CrossRef]

7. Vizcaino, A.J.; Carrero, A.; Calles, J.A. Hydrogen production by ethanol steam reforming over Cu-Ni supported catalysts. Int. J. Hydrogen Energy 2007, 32, 1450-1461. [CrossRef]

8. Snytnikov, P.V.; Badmaev, S.D.; Volkova, G.G.; Potemkin, D.I.; Zyryanova, M.M.; Belyaev, V.D. Catalysts for hydrogen production in a multifuel processor by methanol, dimethyl ether and bioethanol steam reforming for fuel cell applications. Int. J. Hydrogen Energy 2012, 37, 16388-16396. [CrossRef]

9. Moraes, T.S.; Borges, L.E.P.; Farrauto, R.; Noronha, F.B. Steam reforming of ethanol on $\mathrm{Rh} / \mathrm{SiCeO}_{2}$ washcoated monolith catalyst: Stable catalyst performance. Int. J. Hydrogen Energy 2018, 43, 115-126. [CrossRef]

10. Palma, V.; Castaldo, F.; Ciambelli, P.; Iaquaniello, G. $\mathrm{H}_{2}$ Production for MC Fuel Cell by Steam Reforming of Ethanol Over MgO Supported Pd, Rh, Ni and Co Catalysts. Appl. Catal. B Environ. 2014, 145, 73-84. [CrossRef]

11. Jia, H.; Zhang, J.; Yu, J.; Yang, X.; Sheng, X.; Xu, H.; Sun, C.; Shen, W.; Goldbach, A. Efficient $\mathrm{H}_{2}$ production via membrane-assisted ethanol steam reforming over $\mathrm{Ir} / \mathrm{CeO}_{2}$ catalyst. Int. J. Hydrogen Energy 2019, 44, 24733-24745. [CrossRef]

12. Morales, M.; Segarra, M. Steam reforming and oxidative steam reforming of ethanol over $\mathrm{La}_{0.6} \mathrm{Sr}_{0.4} \mathrm{CoO}_{3}-\delta$ perovskite as catalyst precursor for hydrogen production. Appl. Catal. A Gen. 2015, 502, 305-311. [CrossRef]

13. Liu, F.; Qu, Y.; Yue, Y.; Liu, G.; Liu, Y. Nano bimetallic alloy of Ni-Co obtained fromLaCox $\mathrm{Ni}_{1-x} \mathrm{O}_{3}$ and its catalytic performance for steam reforming of ethanol. RSC Adv. 2015, 5, 16837-16916.

14. Moraes, T.S.; Neto, R.C.R.; Ribeiro, M.C.; Mattos, L.V.; Kourtelesis, M.; Ladas, S. Thestudy of the performance of PtNi/CeO $2^{-}$ nanocube catalysts for low temperaturesteam reforming of ethanol. Catal. Today 2015, 242, 35-49. [CrossRef]

15. Chiou, J.Y.Z.; Lee, C.-L.; Ho, K.-F.; Huang, H.-H.; Yu, S.-W.; Wang, C.-B. Catalytic performance of Pt-promoted cobalt-based catalysts for the steam reforming of ethanol. Int. J. Hydrogen Energy 2014, 39, 5653-5662. [CrossRef]

16. Wang, F.; Cai, W.; Provendier, H.; Schuurman, Y.; Descorme, C.; Mirodatos, C. Hydrogen production from ethanol steam reforming over $\mathrm{Ir} / \mathrm{CeO}_{2}$ catalysts: Enhanced stability by $\mathrm{PrO}_{\mathrm{x}}$ promotion. Int. J. Hydrogen Energy 2011, 36, 13566-13574. [CrossRef]

17. Hamryszak, Ł.; Madej-Lachowska, M.; Kulawska, M.; Ruggiero-Mikołajczyk, M.; Samson, K.; Śliwa, M. Investigation on binary copper-based catalysts used in the ethanol steam reforming process. React. Kinet. Catal. Mech. 2020, 130, 727-739. [CrossRef]

18. Fajardo, H.V.; Longo, E.; Mezalira, D.; Nuernberg, G.; Almerindo, G.; Collasiol, A.; Probst, L.F.D.; Garcia, I.T.S.; Carreño, N.L.V. Influence of support on catalytic behavior of nickel catalysts in the steam reforming of ethanol for hydrogen production. Environ. Chem. Lett. 2010, 8, 79-85. [CrossRef]

19. Araiza, D.G.; Gómez-Cortés, A.; Díaz, G. Effect of ceria morphology on the carbon deposition during steam reforming of ethanol over $\mathrm{Ni} / \mathrm{CeO}_{2}$ catalysts. Catal. Today 2020, 349, 235-243. [CrossRef]

20. Fatsikostas, A.N.; Kondarides, D.I.; Verykios, X.E. Production of hydrogen for fuel cells by reformation of biomass-derived ethanol. Catal. Today 2002, 75, 145-155. [CrossRef]

21. Rossetti, I.; Lasso, J.; Finocchio, E.; Ramis, G.; Nichele, V.; Signoretto, M.; Di Michele, A. TiO ${ }_{2}$-supported catalysts for the steam reforming of ethanol. Appl. Catal. A Gen. 2014, 477, 42-53. [CrossRef]

22. Pinton, N.; Vidal, M.V.; Signoretto, M.; Martínez-Arias, A.; Cortés Corberán, V. Ethanol steam reforming on nanostructured catalysts of $\mathrm{Ni}, \mathrm{Co}$ and $\mathrm{CeO}_{2}$ : Influence of synthesis method on activity, deactivation and regenerability. Catal. Today 2017, 296, 135-143. [CrossRef]

23. Li, S.; Li, M.; Zhang, C.; Wang, S.; Ma, X.; Gong, J. Steam reforming of ethanol over $\mathrm{Ni} / \mathrm{ZrO}_{2}$ catalysts: Effect of support on product distribution. Int. J. Hydrogen Energy 2012, 37, 2940-2949. [CrossRef] 
24. Bergamaschi, V.S.; Carvalho, F.M.S.; Rodrigues, C.; Fernandes, D.B. Preparation and evaluation of zirconia microspheres as inorganic exchanger in adsorption of copper and nickel ions and as catalyst in hydrogen production from bioethanol. Chem. Eng. J. 2005, 112, 153-158. [CrossRef]

25. Ni, M.; Leung, D.Y.C.; Leung, M.K.H. A review on reforming bio-ethanol for hydrogen production. Int. J. Hydrogen Energy 2007, 32, 3238-3247. [CrossRef]

26. Sharma, Y.C.; Kumar, A.; Prasad, R.; Upadhyay, S.N. Ethanol steam reforming for hydrogen production: Latest and effective catalyst modification strategies to minimize carbonaceous deactivation. Renew. Sustain. Energy Rev. 2017, 74, 89-103. [CrossRef]

27. Madej-Lachowska, M.; Moroz, H.; Wyżgoł, H.; Hamryszak, Ł. The investigation of activity the bimetallic catalysts based on nickel oxide, cobalt oxide, cerium oxide in ethanol steam reforming (ESR). In Research Papers of the Institute of Chemical Engineering; Polish Academy of Sciences: Warsaw, Poland, 2017; Volume 21, pp. 99-117.

28. Batista, M.S.; Santos, R.K.S.; Assaf, E.M.; Assaf, J.M.; Ticianelli, E.A. High efficiency steam reforming of ethanol by cobalt-based catalysts. J. Power Sources 2004, 134, 27-32. [CrossRef]

29. Augusto, B.L.; Ribeiro, M.C.; Aires, F.J.C.S.; da Silva, V.T.; Noronha, F.B. Hydrogen production by the steam reforming of ethanol over cobalt catalysts supported on different carbon nanostructures. Catal. Today 2020, 344, 66-74. [CrossRef]

30. Greluk, M.; Rotko, M.; Słowik, G.; Turczyniak-Surdacka, S. Hydrogen production by steam reforming of ethanol over $\mathrm{Co} / \mathrm{CeO}_{2}$ catalysts: Effect of cobalt content. J. Energy Inst. 2019, 92, 222-238. [CrossRef]

31. Kulawska, M.; Madej-Lachowska, M.; Hamryszak, Ł.; Moroz, H.; Wyżgoł, H. Application of copper catalyst to the hydrogen production by steam reforming of ethanol. Przem. Chem. 2019, 98, 1992-1995.

32. de Lima, S.M.; Silva, A.M.; Graham, U.M.; Jacobs, G.; Davis, B.H.; Mattos, L.V. Ethanol decomposition and steam reforming of ethanol over $\mathrm{CeZrO}_{2}$ and $\mathrm{Pt} / \mathrm{CeZrO}_{2}$ catalyst: Reaction mechanism and deactivation. Appl. Catal. A Gen. 2009, 352, 95-113. [CrossRef]

33. Dan, M.; Mihet, M.; Tasnadi-Asztalos, Z.; Imre-Lucaci, A.; Katona, G.; Lazar, M.D. Hydrogen production by ethanol steam reforming on nickel catalysts: Effect ofsupport modification by $\mathrm{CeO}_{2}$ and $\mathrm{La}_{2} \mathrm{O}_{3}$. Fuel 2015, 147, 260-268. [CrossRef]

34. Montero, C.; Remiro, A.; Arandia, A.; Benito, P.L.; Bilbao, J.; Gayubo, A.G. Reproducible performance of a Ni/La $\mathrm{L}_{3}-\alpha \mathrm{Al}_{2} \mathrm{O}_{3}$ catalyst in ethanol steam reforming under reaction-regeneration cycles. Fuel Process. Technol. 2016, 152, 215-222. [CrossRef]

35. Xiao, Z.; Wu, C.; Wang, L.; Xu, J.; Zheng, Q.; Pan, L.; Zou, J.; Zhang, X.; Li, G. Boosting hydrogen production from steam reforming of ethanol on nickel by lanthanum doped ceria. Appl. Catal. B Environ. 2021, 286, 119884-119897. [CrossRef]

36. Kim, D.; Kwak, B.S.; Park, N.-K.; Han, G.B.; Kang, M. Dynamic hydrogen production from ethanol steam-reforming reaction on $\mathrm{N}_{\mathrm{ix}} \mathrm{M}_{\mathrm{oy}} / \mathrm{SBA}-15$ catalytic system. Int. J. Energy Res. 2015, 39, 279-292. [CrossRef]

37. Barroso, M.N.; Gomez, M.F.; Arrua, L.A.; Abello, M.C. Hydrogen production by ethanol reforming over NiZnAl catalysts. Appl. Catal. A Gen. 2006, 304, 116-123. [CrossRef]

38. Anjaneyulu, C.; da Costa, L.O.O.; Ribeiro, M.C.; Rabelo-Neto, R.C.; Mattos, L.V.; Venugopal, A.; Noronh, F.B. Effect of Zn addition on the performance of $\mathrm{Ni} / \mathrm{Al}_{2} \mathrm{O}_{3}$ catalyst for steam reforming of ethanol. Appl. Catal. A Gen. 2016, 519, 85-98. [CrossRef]

39. Fang, W.; Paul, S.; Capron, M.; Biradar, A.V.; Umbarkar, S.B.; Dongare, M.K. Highlyloaded well dispersed stable Ni species in $\mathrm{Ni}_{X} \mathrm{Mg}_{2} \mathrm{AlO}_{Y}$ nanocomposites: Applicationto hydrogen production from bioethanol. Appl. Catal. B Environ. 2015, 166, 485-496. [CrossRef]

40. Sohrabi, S.; Irankhah, A. Synthesis, characterization, and catalytic activity of $\mathrm{Ni} / \mathrm{CeMnO}_{2}$ catalysts promoted by copper, cobalt, potassium and iron for ethanol steam reforming. Int. J. Hydrogen Energy. 2021, 46, 12846-12856. [CrossRef]

41. Das, N.K.; Dalai, A.K.; Ranganathan, R. Hydrogen Yield from Low Temperature Steam Reforming of Ethanol. Can. J. Chem. Eng. 2007, 85, 92-100. [CrossRef]

42. Śliwa, M.; Samson, K. Steam reforming of ethanol over copper-zirconiabased catalysts doped with Mn, Ni, Ga. Int. J. Hydrogen Energy 2021, 46, 555-564. [CrossRef]

43. Dancini-Pontes, I.; DeSouza, M.; Silva, F.A.; Scaliante, M.H.N.O.; Alonso, C.G.; Bianchi, G.S.; Neto, A.M.; Pereira, G.M.; FernandesMachado, N.R.C. Influence of the $\mathrm{CeO}_{2}$ and $\mathrm{Nb}_{2} \mathrm{O}_{5}$ supports and the inert gas in ethanol steamreforming for $\mathrm{H}_{2}$ production. Chem. Eng. J. 2015, 273, 66-74. [CrossRef]

44. Chen, L.-C.; Lin, S.D. Effects of the pretreatment of $\mathrm{CuNi} / \mathrm{SiO}_{2}$ on ethanol steam reforming: Influence of bimetal morphology. Appl. Catal. B Environ. 2014, 148-149, 509-519. [CrossRef]

45. Donga, X.-F.; Zoub, H.-B.; Lin, W.-M. Effect of preparation conditions of $\mathrm{CuO}-\mathrm{CeO}_{2}-\mathrm{ZrO}_{2}$ catalyst on $\mathrm{CO}$ removal from hydrogenrich gas. Int. J. Hydrogen Energy 2006, 31, 2337-2344. [CrossRef]

46. Ziółek, M.; Nowak, I. Kataliza Heterogeniczna-Wybrane Zagadnienia; Wydawnictwo Naukowe UAM: Poznań, Poland, 1999.

47. Bahari, M.B.; Phuc, N.H.H.; Abdullah, B.; Alenazey, F.; Vo, D.-V.N. Ethanol dry reforming for syngas production over Ce-promoted $\mathrm{Ni} / \mathrm{Al}_{2} \mathrm{O}_{3}$ catalyst. J. Environ. Chem. Eng. 2016, 4, 4830-4838. [CrossRef]

48. Basahel, S.N.; Mokhtar, M.; Alsharaeh, E.H.; Ali, T.T.; Mahmoud, H.A.; Narasimharao, K. Physico-Chemical and Catalytic Properties of Mesoporous $\mathrm{CuO}-\mathrm{ZrO}_{2}$ Catalysts. Catalysts 2016, 6, 57-77. [CrossRef]

49. Gao, P.; Li, F.; Zhan, H.J.; Zhao, N.; Xiao, F.K.; Wei, W.; Zhong, L.S.; Wang, H.; Sun, Y.H. Influence of Zr on the performance of $\mathrm{Cu} / \mathrm{Zn} / \mathrm{Al} / \mathrm{Zr}$ catalysts via hydrotalcite-like precursors for $\mathrm{CO}_{2}$ hydrogenation to methanol. J. Catal. 2013, 298, 51-60. [CrossRef]

50. Díez, V.K.; Apesteguía, C.R.; Di Cosimo, J.I. Acid-base properties and active site requirements for elimination reactions on alkali-promoted MgO catalysts. Catal. Today 2000, 63, 53-62. [CrossRef] 
51. Baneshi, J.; Haghighi, M.; Jodeiri, N.; Abdollahifar, M.; Ajamein, H. Homogeneous precipitation synthesis of $\mathrm{CuO}_{-} \mathrm{ZrO}_{2}-\mathrm{CeO}_{2}-$ $\mathrm{Al}_{2} \mathrm{O}_{3}$ nanocatalyst used in hydrogen production via methanol steamreforming for fuel cell applications. Energy Convers. Manage. 2014, 87, 928-937. [CrossRef]

52. Wang, G.; Zuo, Y.; Han, M.; Wang, J. Copper crystallite size and methanol synthesis catalytic property of Cu-based catalysts promoted by Al, Zr and Mn. Reac. Kinet. Mech. Cat. 2010, 101, 443-454. [CrossRef]

53. Mastalir, A.; Frank, B.; Szizybalski, A.; Soerijanto, H.; Deshpande, A.; Niederberger, M.; Schomäcker, R.; Schlögl, R.; Ressler, T. Steam reforming of methanol over $\mathrm{Cu} / \mathrm{ZrO}_{2} / \mathrm{CeO}_{2}$ catalysts: A kinetic study. J. Catal. 2005, 230, 464-475. [CrossRef]

54. Binet, C.; Daturi, M.; Lavalley, J.C. IR study of polycrystalline ceria properties in oxidised and reduced states. Catal. Today 1999, 50, 207-225. [CrossRef]

55. Ebiad, M.A.; Abd El-Hafiz, D.R.; Elsalamony, R.A.; Mohamed, L.S. Ni supported high surface area $\mathrm{CeO}_{2}-\mathrm{ZrO}_{2}$ catalysts for hydrogen production from ethanol steam reforming. RSC Adv. 2012, 2, 8145-8156. [CrossRef]

56. Wang, J.H.; Lee, C.S.; Lin, M.C. Mechanism of ethanol reforming: Theoretical foundations. J. Phys. Chem. C. 2009, 113, 6681-6688. [CrossRef]

57. Mattos, L.V.; Jacobs, G.; Davis, B.H.; Noronha, F.B. Production of hydrogen from ethanol: Review of reaction mechanism and catalyst deactivation. Chem. Rev. 2012, 112, 4094-4123. [CrossRef] [PubMed]

58. Song, J.H.; Yoo, S.; Yoo, J.; Park, S.; Gim, M.Y.; Kim, T.H.; Song, I.K. Hydrogen production by steam reforming of ethanol over $\mathrm{Ni} / \mathrm{Al}_{2} \mathrm{O}_{3}-\mathrm{La}_{2} \mathrm{O}_{3}$ xerogel catalysts. Mol. Catal. 2017, 434, 123-133. [CrossRef]

59. Sharma, P.K.; Saxena, N.; Bhatt, A.; Rajagopal, C.; Roy, P.K. Synthesis of mesoporous bimetallic Ni-Cu catalysts supported over $\mathrm{ZrO}_{2}$ by a homogenous urea coprecipitation method for catalytic steam reforming of ethanol. Catal. Sci. Technol. 2013, 3, 1017-1026. [CrossRef]

60. Cai, W.; Wang, F.; Zhan, E.; Van Veen, A.C.; Mirodatos, C.; Shen, W. Hydrogen production from ethanol over Ir/CeO 2 catalysts: A comparative study of steam reforming, partial oxidation and oxidative steam reforming. J. Catal. 2008, 257, 96-107. [CrossRef]

61. Courty, P.; Ajot, H.; Marcilly, C.; Delmon, B. Oxydesmixtesou en solution solide sous formetrèsdiviséeobtenus par décompositionthermique de précurseursamorphes. Powder Technol. 1973, 7, 21-38. [CrossRef]

62. Lachowska, M. Steam reforming of methanol over $\mathrm{Cu} / \mathrm{Zn} / \mathrm{Zr} / \mathrm{Ga}$ catalyst: Effect of the reduction conditions on the catalytic performance. Reac. Kinet. Mech. Cat. 2010, 101, 85-91. [CrossRef]

63. Żelazny, A.; Samson, K.; Grabowski, R.; Śliwa, M.; Ruggiero-Mikołajczyk, M.; Kornas, A. Hydrogenolysis of glycerol to propylene glycol over $\mathrm{Cu}$ /oxide catalysts: Influence of the support and reaction conditions. Reac. Kinet. Mech. Cat. 2017, 121, 329-343. [CrossRef]

64. Szarawara, J.; Skrzypek, J.; Gawdzik, A. Podstawy Inżynierii Reaktorów Chemicznych, 2nd ed.; WNT: Warsaw, Poland, 1991; pp. 20-45. 